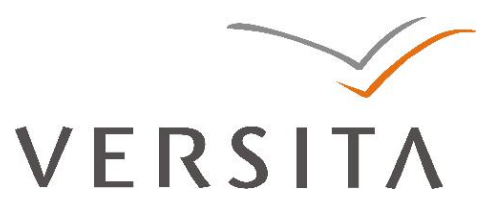

\title{
Integration Potential of the European Neighbourhood Policy
}

\author{
Veronika Sklenková \\ Faculty of Social Sciences of the Ss. Cyril and Methodius University in Trnava
}

\begin{abstract}
Integration Potential of the European Neighbourhood Policy. The aim of this paper is to examine the actual integration potential of the European Neighbourhood Policy and its related regional initiative - Eastern Partnership for the countries of the Eastern Europe that currently do not have an official perspective of the EU membership. Based on the analysis of official documents we would like to assess the benefits that EU offers to its neighbours under this policy in return for certain reforms and in doing so to analyse the degree of exogenous integration it actually enables to achieve. We assume that for the time being the EU's European Neighbourhood Policy aims to provide the neighbour countries with an alternative to the accession process since neither the EU nor the neighbour countries are now ready for their potential membership. However, this alternative could have a significant integration potential (even though without a full EU membership as the last step) if all the rules are complied with and the procedures are consistently followed. To support our postulate, we compare the mechanisms and instruments of this policy with those used during the EU enlargement process.
\end{abstract}

Key words: European Neighbourhood Policy, European Union, integration, Eastern Partnership, enlargement

\begin{abstract}
Integračný potenciál Európskej politiky susedstva. Ciel'om článku je skúmat' a zhodnotit' integračný potenciál Európskej politiky susedstva a s ňou súvisiacej regionálnej iniciatívy - Východné partnerstvo pre krajiny východnej Európy, ktoré v súčasnosti nemajú oficiálne perspektívu členstva $v$ EÚ. Na základe analýzy oficiálnych dokumentov o vytvorení Európskej politiky susedstva a jej neskoršej integrálnej súčasti - Východného partnerstva, by sme chceli zhodnotit výhody, ktoré EÚ svojim susedom v rámci tejto politiky ponúka výmenou za určité reformy a zároveň analyzovat' stupeň exogénnej integrácie, ktorý táto politika vlastne umožňuje dosiahnut ${ }^{1}$. Predpokladáme, že v súčasnej dobe si EÚ v rámci Európskej politiky susedstva kladie za ciel' poskytnút' susedným krajinám alternatívu k prístupovému procesu, nakol'ko ani EÚ, ani susedné krajiny nie sú momentálne pripravené na ich prípadné členstvo. Táto alternatíva by však mohla mat' významný integračný potenciál (aj ked' bez plného členstva $v$ EÚ), pokial' by boli striktne dodržiavané všetky pravidlá a splnené všetky podmienky. Aby sme podporili náš predpoklad, budeme porovnávat' mechanizmy a nástroje tejto politiky $s$ tými, ktoré boli využité v procese rozširovania EÚ.
\end{abstract}

Klúčové slová: Európska politika susedstva, Európska únia, integrácia, Východné partnerstvo, rozšírenie

\footnotetext{
${ }^{1}$ Due to the limited range, this paper doesn't seek to provide a full and deep analysis of the evolution and functioning of the European Neighbourhood Policy including its specific dimension - the Eastern Partnership. It focuses only on the specific topic of the level of integration with the EU it actually enables to achieve for the eastern European neighbours as it is stated in the official documents establishing and reinforcing this policy. For a comprehensive analysis see: Sklenková, V. 2010. Integračný potenciál Európskej politiky susedstva: perspektívy krajín východnej dimenzie. Dizertačná práca. Fakulta politických vied a medzinárodných vzt’ahov UMB, Banská Bystrica 2010, $182 \mathrm{~s}$.
}

Slovak Journal of Political Sciences, Volume 12, 2012, No. 1

DOI: 10.2478/sjps-2013-0003 


\section{Introduction}

From its very inception European integration has proved to be a successful project bringing together democratic countries of the European continent with the aim to jointly ensure stability, security and prosperity on this continent. As time passed, the benefits of integration have attracted most of the western European countries that initially were not interested in joining the original European Coal and Steel Community in the 1950s. After more than fifty years of evolution, the current integration project - the European Union - integrates 27 member states, with five candidate states waiting for membership ${ }^{2}$, three states having an official perspective of joining the $\mathrm{EU}^{3}$ and several western European states that are not members of the EU but enjoy the same benefits of economic integration, namely the common market, within the framework of European Economic Area ${ }^{4}$. After the ten countries of Central and Eastern Europe joined the EU in 2004 and 2007, the European integration project finally managed to officially reunite the western and the eastern part of the European continent after it had been divided by the Cold War for several decades.

It cannot be said that the European continent is completely reunited, though. Even though the Treaty on the European Union states that every European country that meets the specified criteria can apply for the EU membership, there are still some European countries that lack the official perspective of future EU membership. These are the countries of Eastern Europe that used to be part of the USSR during the Cold War, namely Ukraine, Belarus, Moldova and also the countries of the Southern Caucasus - Georgia, Armenia and Azerbaijan. Position of these countries with regard to the European integration is rather problematic given several reasons. One of them is their geographic position in the shared neighbourhood of the EU and the Russian Federation which both of the actors claim to be their sphere of influence; another one is their disputed European character and even pro-European orientation (in case of the Sothern Caucasus countries); but mostly the main officially declared reason for them to being denied the official perspective of EU membership for

\footnotetext{
${ }^{2}$ Croatia, Iceland, Turkey, Macedonia and Montenegro

3 Albania, Bosnia and Herzegovina and Serbia (including Kosovo under the UN Security Council Resolution N. 1244

${ }^{4}$ Lichtenstein, Norway and Iceland (official EU candidate country but belongs also to this group). Switzerland does not take part in the EEA but also maintains special relationship with the EU at the level of common market but based on several bilateral sectoral agreements and association agreement.
}

Slovak Journal of Political Sciences, Volume 12, 2012, No. 1

DOI: $10.2478 /$ sjps-2013-0003 
the time being is the fact that they significantly fail to meet the necessary criteria for being even considered as a future member.

However, the European Union wants to maintain close relationship with the countries in its immediate neighbourhood since what happens in its vicinity directly affects the Union itself. This is the main reason why the EU needs to have a stable, secure and prosperous neighbourhood as well. In this regard, in 2004 the EU created a new policy framework for its relations with the aforementioned countries under which it seeks to support democratic transition of these countries by assisting them financially, technically and also politically. This policy is called the European Neighbourhood Policy (ENP) and besides the European neighbour countries it includes also neighbours of the EU from Northern Africa and Middle East.

Some of the neighbours from Eastern Europe declare EU membership aspirations and therefore are discontented with being in the same policy framework of relations as non-European countries and they continually claim the official perspective of membership. In order to reflect the specifics in relations to the eastern European countries, the EU created a new regional initiative under the framework of ENP - the Eastern partnership which provides for closer connection of the EU and the eastern neighbours. Our aim is to examine the potential of both the ENP itself and its initiative Eastern Partnership for closer integration of the European neighbours and the options they bring for maintaining special relationships with or without a full membership perspective.

\section{European neighbourhood policy and the Eastern European neighbour countries}

The European Neighbourhood Policy is a comprehensive strategy for European Union's relations with its sixteen neighbouring countries ${ }^{5}$. Although majority of the countries have already established contractual relationship with the EU many years ago (the southern Mediterranean countries, moreover, have also established multilateral cooperation in form of the Euro-Mediterranean partnership), the new policy gave these relationships a comprehensive and unifying framework. In order to create a "zone of stability, security and prosperity" in the EU's immediate neighbourhood, and in doing so to ensure its own internal security, the ENP provides EU's neighbours with a privileged

\footnotetext{
${ }^{5}$ Official status of a neighbour country under the framework of the ENP is granted to every country that shares a common land or maritime border with one or more EU member states or with EU candidate and prospective candidate states. The only exemption is Russian Federation whose relations with the EU are covered by the framework of Strategic Partnership and Four Common Spaces.
}

Slovak Journal of Political Sciences, Volume 12, 2012, No. 1

DOI: $10.2478 /$ sjps-2013-0003 
partnership in return for carrying out a series of reforms that would lead to a democratic transition in these countries. The progress achieved in the reform process will be rewarded by a new generation of bilateral agreements in the form of so-called European Neighbourhood Agreements ${ }^{6}$, which will provide basis for closer integration of the EU and the ENP countries.

In general, we can summarize the advantages and incentives the ENP offers to the neighbouring countries, as follows (Kelley, 2006):

- Possibility of intensifying mutual relations and transforming them from level of cooperation to some level of integration. The Commission offers the neighbouring countries possibility to participate in the functioning of the internal market, as well as the opportunity to gradually get involved in some key EU policies and programs.

- Enhancement and intensification of mutual political cooperation.

- Deepening of trade and economic relations.

- Increasing of financial support.

- Reducing barriers to trade, opening of economies.

- Participation in the Community programmes supporting cooperation in culture, education, science, technology, and environment.

- Support for legislative approximation towards European norms and standards.

Principles, methods and instruments of cooperation of the EU and its partner countries in achieving reforms under the ENP are set out in the European Neighbourhood Policy Strategy Paper. It states that the existing contractual relations between the EU and individual partner countries continue to provide the basis also for this type of cooperation. In the case of the southern Mediterranean neighbours are the contractual relationships based on association agreements; on the other hand, the countries of Eastern Europe and South Caucasus have concluded partnership and cooperation agreements with the EU. Currently, the ENP cannot be fully realized with three neighbours included in its geographical scope - with Belarus, Libya and Syria. As for Belarus, the European Union has not entered into a contractual relationship with this country because of its undemocratic regime.

The main instruments of the European Neighbourhood Policy are action plans, in which the EU in cooperation with individual neighbours defines the priorities and specific steps to achieve the necessary reforms. Before developing a concrete action plan with the partner country, the Commission shall submit a country report evaluating the current state of relations, as well as

\footnotetext{
${ }^{6}$ Provisional name used by the European Neighbourhood Policy Strategy Paper. Currently, it is already known that these new agreements will have form of specific association agreement.
}

Slovak Journal of Political Sciences, Volume 12, 2012, No. 1

DOI: $10.2478 /$ sjps-2013-0003 
political, economic and social development in the country and identifying a number of problems solutions to which are to be elaborated in detail in the action plan. After its preparation and approval, the action plan presents an essential reference point for the implementation of concrete steps to support and monitor progress. The action plan, as one of the main tools of the ENP, defines the main areas of reform agenda, as well as concrete steps and shortterm and medium term priorities for the country. Action plans are negotiated for a period of 3-5 years. They are tailored to individual countries' needs; in general, they have a similar structure, though. Action plans are negotiated and concluded in cooperation of both parties, the EU and partner countries, mostly through joint bodies set up by mutual contractual relations - either the Association Council or Cooperation Council. Action plans, unlike the association agreements and partnership and cooperation agreements they are based on, are only documents of a political nature and are therefore not legally binding. In the event that some provisions and obligations of an action plan are not met in a specified period of 3-5 years, there will be no legal consequences and no legal sanctions can be imposed on the country. The EU can, however, draw the consequences of political and financial nature in relation to such a country, for example it can restrict or suspend the assistance provided in the area in question.

After the action plans are approved, their implementation is regularly monitored both by the Commission and partner countries. Fulfilment of mutual obligations is supervised and compliance with the stated objectives is controlled. For this purpose, the Commission shall issue regular progress reports on individual countries, in which it also identifies shortcomings in the implementation of action plans. The progress in implementing reforms in different sectors is monitored by joint subcommittees of both partners. In this way, joint ownership of the whole reform process should be ensured.

The EU supports the implementation of reform steps in the neighbouring countries by providing financial assistance as well as technical support. For the purpose of financial support it has created a special financial instrument funded from the EU budget called the European Neighbourhood and Partnership Instrument. This instrument is operational since the beginning of the current EU financial period $2007-2013$ and it aims to provide financial assistance for achieving the objectives and priorities of individual action plans, achieving sustainable development of neighbouring countries, as well as bringing them closer to values, norms and standards of the $\mathrm{EU}$ in order to achieve their potential involvement in certain aspects of the functioning of the EU, e.g. the common market, certain EU policies, participation in EU programs and agencies, etc. For the period 2007 - 2013 the EU allocated an amount of about 12 billion euros to finance support for reforms in the neighbour countries under

Slovak Journal of Political Sciences, Volume 12, 2012, No. 1

DOI: 10.2478/sjps-2013-0003 
the European Neighbourhood and Partnership Instrument (European Commission, 2003b).

Additional funding can be acquired based on the merit principle through the Governance Facility. Those countries that have made the biggest progress in implementing reform measures in accordance with the agreed action plans can benefit from this mechanism. For this purpose, the EU allocated the amount of 300 million euros for the period 2007 - 2013. Neighbour countries also have the possibility to obtain loans from the Neighbourhood Investment Facility to cover their investment needs in building infrastructure, in transport and energy sectors as well as environmental and social issues (building schools and hospitals).

The Commission has allocated funds amounting to 700 million euros from this facility for the financial period $2007-2013$.

In addition to providing funds, the European Union supports the reform processes in the neighbouring countries through the mechanisms of technical support - TAIEX and Twinning, which have already proven as a suitable tool for pre-accession assistance from the EU during the transformation process in Central and Eastern Europe. They are used even today in the pre-accession process of Western Balkan countries. Both mechanisms are aimed to assist the neighbouring countries in aligning the relevant part of their legislation with the EU legislation, and also in building stable and democratic institutions.

Based on regular monitoring, the EU assesses the progress made by individual neighbours in achieving their action plans and if the level of reforms is sufficient, the Union may proceed to the next step in intensifying mutual relations and deepening of integration - the conclusion of a new type of agreement with the country (replacing the former action plan), which will form the legal basis for closer integration of the neighbour country with the EU. The scope and contents of the agreement is subject to rather complicated and protracted negotiations and bargaining between the EU and the respective neighbour countries based on the actual situation and conditions on both sides.

\section{Enlargement policy as a methodological model for European Neighbour-} hood policy

Although the enlargement policy does not primarily count among the EU external policies, it became virtually the most successful form of the EU foreign policy. By means of this particular policy, the Union can act effectively on what is happening in its immediate surroundings and influence the political and economic developments outside its borders. Remarkably effective transformational potential of this policy strongly manifested during the 90's, just when the EU accession process became a catalyst for pro-democratic changes in Central and Eastern Europe.

Slovak Journal of Political Sciences, Volume 12, 2012, No. 1

DOI: $10.2478 /$ sjps-2013-0003 
European Union and its top officials are aware of the positive impact the enlargement policy has on the candidate countries (see e.g. European Commission, 2004a) and also that thanks to this policy the EU enjoys status of a "normative power". Although the EU enlargement process is currently slowed down and the benefits of this policy cannot be automatically used in relation to all countries in the immediate vicinity of the EU, the Union decided to use the transformative potential of this policy and to transfer it to the greatest possible extent into a new platform of relations with those European countries to which, at least in the foreseeable future, the enlargement policy will not apply. In general, we found that the European Neighbourhood Policy was modelled after the pattern of enlargement policy and strives to maintain all effective tools and mechanisms that have proved successful during the accession process of the 12 new member states. It is particularly for the ENP's methodological similarity to the enlargement policy that this new EU external relations policy is being compared to "new wine in old wineskins" (Kelley, 2006). However, critics of this policy point out the fact that the ENP will never be able to repeat the transformation success of the enlargement policy since it's missing the main and most effective stimulus, and that's the EU membership as a reward for carrying out all the necessary and often painful reforms (e.g. Tassinari, 2005; Kelley, 2006, etc.).

European Commission, as the main institution responsible for managing of the accession process for EU enlargement, played also primary role in modelling the form of the new policy. The very fact that the new policy was shaped by people actively involved in the process of EU enlargement has contributed to what the authors call "mechanical borrowing from enlargement experiences" (Kelley, 2006, p. 29), resulting in a so-called "shadow of enlargement", as the ENP is also sometimes referred to (Magen, 2006, p. 383). Criticism of this approach is directed mainly to the fact that the Commission has tried to apply the methodology used in the enlargement process within a completely different political context and on a completely different situation, which some authors consider inadequate (Magen 2006, Cremona, Hillion 2006, Gebhard, 2007). R. Prodi, one of the initiators of the new policy, advocates the chosen methodology and responds to the criticism of the absence of the socalled "golden carrot" in the form of EU membership as follows: "The goal of accession is certainly the most powerful stimulus for reform we can think of. But why should a less ambitious goal not have some effect?" (Prodi, 2002).

The European Neighbourhood Policy, as established by the European Commission, is result of a combination of policy learning and adaptation of the experience gained in the enlargement process in response to the new, changed circumstances of post-enlargement reality (Kelley 2006). Three factors have played an important role in developing of its methodology: path dependency,

Slovak Journal of Political Sciences, Volume 12, 2012, No. 1

DOI: 10.2478/sjps-2013-0003 
learning from past experience and adaptation (Kelley 2006, Magen 2006, Gebhard, 2007). The term "path dependency" means how the past choices and decisions influence the present institutional options (Pierson, 1996). In this case, the term "learning" is defined as "application of insights about causal relationships from past behaviours to solve new problems," while the term "adaptation" refers to "application of prior causal beliefs to new situations" (Kelley, 2006, pp. 30-31).

According to J. Kelley, it was the element of path dependency that was significantly present in the process of formation of the ENP, as evidenced by the fact that this policy was formulated and subsequently officially created by the Directorate General for Enlargement, and has only later been moved to the scope of the Directorate General for External Relations. J. Kelley sees the creation of this policy in order to extend the Commission's EU foreign policy mandate as a "strategic adaptation to changes in the external environment" (Kelley, 2006, p. 31).

The aforementioned mechanical borrowing of ENP methods from the previous policies, especially the enlargement policy, is evident in two basic levels - strategic and operational (Gebhard, 2007). At the strategic level, the concept of ENP is based on two basic principles derived from the enlargement policy - principle of conditionality and principle of socialization. At the operational level, the results of the mechanical borrowing from the EU enlargement policy are in particular the ENP instruments - action plans and instruments for monitoring and evaluation of progress.

Strict application of the principle of conditionality was the main reason for transformational success of the EU enlargement policy and conditionality is also now a fundamental principle of the ENP. Although it lacks the strongest motive that could intensively encourage neighbouring states to undertake the reforms, the ENP, however, provides a range of other already mentioned incentives that will allow closer integration of neighbours with the EU after fulfilling the necessary conditions.

European Commission Communication "Wider Europe - Neighbourhood: A New Framework for Relations with our Eastern and Southern Neighbours" published in 2003 in this regard says that "in return for concrete progress demonstrating shared values and effective implementation of political, economic and institutional reforms, including in aligning legislation with the acquis, the EU's neighbourhood should benefit from the prospect of closer economic integration with the EU. To this end, ...countries ... should be offered the prospect of a stake in the EU's Internal Market and further integration and liberalisation to promote the free movement of - persons, goods, services and capital (four freedoms)" (European Commission, 2003a, p.4). The original intention was to put the same emphasis on rigorous

Slovak Journal of Political Sciences, Volume 12, 2012, No. 1

DOI: $10.2478 /$ sjps-2013-0003 
conditionality within the ENP as it was within the enlargement policy and set precise measurable benchmarks for assessing the progress of reform of individual countries. According to the Communication Wider Europe "engagement should therefore be introduced progressively, and be conditional on meeting agreed targets for reform" and "clear and public objectives and benchmarks" should also be set. Former European Commission president, R. Prodi, was one of the main proponents of strict observance of the principle of conditionality. Even in his original proposal of the "proximity policy" in 2002 he proposed to follow a rigorous conditionality, as in the case of the enlargement policy. He claimed that "we need to set benchmarks to measure what we expect our neighbours to do in order to advance from one stage to another. We might even consider some kind of "Copenhagen proximity criteria" (Prodi, 2002).

However, the rhetoric of the Commission in connection with a strict conditionality has gradually changed, since the relationship between the EU and neighbouring countries is inherently of a different nature than the relationship between the EU and the candidate countries. For the principle of conditionality to be consistently applied, an asymmetry of power should exist in mutual relations of both sides. One side must be in a position to have the power to enforce compliance with its strictly defined conditions, while the other one wants and needs to fulfil these conditions in their own interest. This situation certainly is a reality in the case of the enlargement policy and the accession process itself, where the conditions are solely set by the European Union and the candidate country must strictly adhere to them if it wants to achieve the objective of EU membership.

However, within the process of adjusting the mechanisms of enlargement policy to the new circumstances of relations with neighbouring countries, the principle of conditionality has been limited by introducing of an innovative principle of joint ownership and principle of partnership. In practice that means that in the case of ENP the terms are not set exclusively by the EU, but the necessary reform steps are always agreed in cooperation with a particular partner country. Such an approach should enhance the ownership of the necessary reforms in the neighbour countries and thus give the reforms in these countries needed credibility. Therefore, the European Neighbourhood Policy Strategy Paper adopted in 2004 in the context of the partnership principle states that "the EU does not seek to impose priorities or conditions on its partners" (European Commission, 2004, p. 8). In this paper, terminology of benchmarks and strict conditionality has been replaced with more general terms of looser conditionality: "the ambition and the pace of development of the EU's relationship with each partner country will depend on its degree of commitment to common values, as well as its will and capacity to implement agreed

Slovak Journal of Political Sciences, Volume 12, 2012, No. 1

DOI: 10.2478/sjps-2013-0003 
priorities" (Commission, 2004, p. 8). Conditionality, however, remains a central principle of the ENP and is effectively complemented by the principle of socialization.

The principle of socialization within the ENP was also transferred from the EU enlargement policy. I. Johnston defines socialization as a conduct when "players make changes in behaviour by creating a recurring pressure through shaming, persuasion and other efforts to socialize state actors" (Johnston, 2001, p. 488). In this sense, it may be particularly useful for the Union to establish cooperation of the Commission with opposition, NGOs and civil society in the neighbouring countries in order to create pressure on their governments and promote effective application of reforms. Union tries to do its best to support reform-orientated political forces in the countries (Kelley, 2006). An important mechanism that promotes socialization in neighbouring countries is the abovementioned twinning, but also the Commission's annual progress reports. These are, on the one hand, means for praising the achieved progress, but on the other hand, they also provide a means for public blaming and shaming of those countries which do not carry out agreed reform priorities or their efforts are insufficient. These progress reports also point out and blame those countries that violate human rights. Linking of conditionality and socialization is best seen in the mechanism which allows for allocation of additional financial resources for those countries that are successful in implementing reforms. This mechanism is based on positive results of monitoring process and progress reports in the neighbour countries.

Compared to the methodology utilized in the enlargement policy, the European Neighbourhood Policy, however, establishes a very important innovative element, and thus the principle of differentiation. While the enlargement policy applies uniform rules and conditions that have to be met to achieve membership in the EU; under the ENP, which doesn't imply full membership perspective for the neighbours even if they consistently apply all agreed reform measures, the conditions and reform measures which must be met, are specific for each of the neighbours. There is no single and final objective within the ENP (as the EU membership is in the case of the enlargement policy). The objective for each neighbour country is the greatest possible degree of integration or connection to the EU based on their achieved reform progress.

Although the ENP establishes a single comprehensive framework for EU's relations with all neighbouring countries, it is primarily based on a bilateral approach to individual countries, which is reflected in the drafting of individual tailored action plans. Applying the principle of differentiation prevents the countries from holding each other back in achieving closer connection to the $\mathrm{EU}$, as opposed to the usual block approach used within the enlargement

Slovak Journal of Political Sciences, Volume 12, 2012, No. 1

DOI: 10.2478/sjps-2013-0003 
policy. In this policy, the Union favours entrance of new Member States in groups within the so called enlargement rounds.

The fact that the ENP has been to a great extent inspired by the enlargement policy is also visible on its operational level. Basic tools of this policy - action plans - were modelled on the pattern of association agreements with the accession countries from Central and Eastern Europe. The so-called country reports, that Commission processed and published prior to negotiation of action plans and whose purpose was to examine and assess the political and economic situation of each country and identify areas of needed reforms, strongly reminiscent of evaluation reports drawn up by the Commission for each applicant country and based on this report the EU Council then decided to grant, or not to the status of a candidate country. The ENP also adapted the tools for monitoring and assessing of achieved progress - annual progress reports of neighbour countries elaborated by the Commission.

Although the European Commission's decision to use the methodology of its most effective transformation policy - the enlargement policy - in order to ensure stability, security and prosperity in its neighbourhood may seem reasonable and logical, it has also provoked some criticism among scholars (e.g. Magen, 2006; Cremona, Hillion, 2006; Meloni, 2007; etc.). The most common argument of critics is usually the absence of the most important incentive, the membership perspective, which significantly reduces the transformation potential of the ENP. In this respect, there is not an adequate balance between the costs and expected benefits by implementation of reforms in neighbouring countries. M. Cremona and Ch. Hillion point out that "transplanting pre-accession routines into a policy otherwise conceived as an alternative to accession and intended to enhance the security of the Union, may however undermine both its current effectiveness and its longer-term viability, if not its rationale" (Cremona, Hillion, 2006 p. 26).

\section{The European Neighbourhood Policy and the integration ambitions of neighbour countries}

The European Union does its best to present the European Neighbourhood Policy as neutral in relation to the EU membership, even though it was the policy of enlargement, its practice and experience that greatly inspired creation of new concept and strategy of relations with neighbouring countries. The main reason for this is mainly the unclear future of the project of further enlargement of the Union, but also of the overall project of European integration as such.

It is obvious that the original concept of today's ENP, which aimed to cover the new eastern neighbours - Ukraine, Belarus and Moldova, was motivated mainly by the EU efforts to tackle the potential integration ambitions of these countries and present them an alternative arrangement for mutual relations in

Slovak Journal of Political Sciences, Volume 12, 2012, No. 1

DOI: 10.2478/sjps-2013-0003 
the conditions of enlargement crisis. The current EU position on integration ambitions of the Eastern European countries and their claim to be provided with a clear perspective of possible future membership could be best describes by the words of E. Landaburu, former Director General of DG RELEX of the European Commission: "Continuing to view our neighbourhood from an enlargement angle is an unhelpful distraction. Remember the saying that one should not ask a question to which one wouldn't like the answer.'(Landaburu, 2006, p. 1).

While the Union seeks to promote Prodi's vision of "everything but institutions" (Prodi, 2002) to all neighbouring countries and strictly rejects any linkage of the question of EU membership with the ENP, positions of partner countries, their perception of the new policy, as well as their expectations in relation to the EU vary considerably. E. Tulmets identifies three different groups of partner countries that perceive and interpret the ENP in a different way. The first group consists of countries that have negotiated either an association agreement or a partnership and cooperation agreement and have a desire to intensify their relations and ties with the Union in various policy areas through negotiating and implementation of action plans. These countries fall within the ENP framework, however, they either do not have legal right to aspire for the EU membership (Morocco, Tunisia, Egypt, Israel, Palestinian Authority), or they do not wish to enter the EU (Armenia, Azerbaijan). The level of intensity of individual countries' relations with the Union may vary depending on their ability to implement action plans, and therefore it is important to put emphasis on differentiation (Tulmets, 2006, p. 51). P. Kratochvil notes that the southern Mediterranean countries, for which the prospect of EU membership is completely ruled out, tend to perceive the ENP as a reinforced Barcelona process (Kratochvil, 2006).

The second group of neighbouring countries consists of those states that do not in fact participate in the ENP, either because they themselves choose not to participate (Belarus, Algeria, Russia ...), or because there is a lack of political consensus within the EU (Belarus, Libya, Syria). These countries' relations with the EU could, however, be mobilized in the future and the aforementioned countries could fully and actively participate in the ENP if there is a change in their internal political situation, increased interest in cooperation with the EU and also acknowledgement by the EU member states that these countries have fulfilled the conditions for intensification of mutual cooperation (Tulmets, 2006).

Last group consists of those neighbour countries that consistently declare their pro-European orientation, as well as the ambition to become future full EU members (or at least to obtain candidate status) and in terms of the EU primary law are, after the fulfilment of certain conditions, in fact entitled to

Slovak Journal of Political Sciences, Volume 12, 2012, No. 1

DOI: 10.2478/sjps-2013-0003 
claim the EU membership (Ukraine, Moldova and Georgia). It is the relationship and the status of these countries under the ENP that is rather problematic. Their perception of the ENP is significantly affected by their integration ambitions and in contrast with the position of the EU they are trying to link the implemented reforms with the topic of EU membership. They basically perceive the ENP itself as a kind of precursor to the EU accession negotiations, or same kind of a waiting room for granting of a candidate status. Such an approach could be in a sense seen as justified. The European Union has never officially given any indication that these countries might apply for its membership in the future, but it has not explicitly excluded this option either. The question of membership of countries of the so called "grey zone" is not currently, nor in the medium term, on the EU agenda and until (if) this changes, in the meantime it is in the interest of the Union to develop close partnerships with neighbouring countries within the ENP. However, inclusion into the ENP of those countries, whose prospect of EU membership is completely excluded, may interfere with the perception of the ENP as a current strategy of the EU relations with hose countries that do not have this perspective only for the time being. This is usually the main point of criticism of this policy by the eastern neighbours.

Another factor that encourages the perception of the ENP as a pre-accession policy is also the aforementioned use of the EU enlargement policy methodology. It is this methodology that sends conflicting signals towards neighbouring countries. M. Cremona and $\mathrm{Ch}$. Hillion highlight the paradox that the application of the enlargement methodology brings along: "the better it succeeds, the less the ENP can legitimately be disconnected from the membership prospect of the eligible partners, because the conditions for membership are de facto being met. In other words, if it works, the ENP will create candidates" (Cremona, Hillion, 2006). In case such a situation becomes reality the only argument left for the EU would be its integration capacity.

On the other hand, it is important to note that despite the fact that the ENP does not offer the prospect of EU membership, it offers possibility of significant integration into many aspects of its operation and access to many benefits of its individual policies. In this sense, the ENP offers neighbouring countries the opportunity to move along the axis of integration. The logic of variable geometry Europe and model of Europe of concentric circles enables these countries to move from the periphery towards the core of integration. Under existing conditions, these countries can gradually gain status similar to the one the members of EFTA currently have in relation to the EU. Such a development would give substance to the phrase "everything but institutions". However, it is highly unlikely that the neighbouring countries with ambitions to gain the full membership would be satisfied with the fact that they could take

Slovak Journal of Political Sciences, Volume 12, 2012, No. 1

DOI: 10.2478/sjps-2013-0003 
part in the integration, but will not be able to shape its rules and development in any way.

\section{Integration potential of alternatives to the enlargement: the European Neighbourhood Policy and the Eastern Partnership}

Although the concern of the European Commission is for the European Neighbourhood Policy to be seen as membership neutral as possible, it is undisputed that it has at least partly emerged as a temporary alternative to the enlargement policy in regard with the countries of the EU's eastern neighbourhood. A clear proof to this is also the well-known statement of R. Prodi, the neighbouring countries should be offered "everything but institutions". This EU offer in the form of ENP can be simply interpreted as the Union's interest in the closest integration of their neighbours into many aspects of its operation, but without the possibility of their involvement into the European institutions and hence also into the decision-making process. Under this policy, neighbouring countries should be able to benefit from all the assets the European integration brings along, but on the other hand, they must unconditionally accept and apply the acquis communautaire, the formation of which they did not influence and they will not have this option in the future either. ENP therefore provides the opportunity to participate in the European integration, but without any real possibility to interfere with its development, operation and scope.

The European Neighbourhood Policy therefore enables some integration of neighbouring countries, namely some form of flexible exogenous integration ${ }^{7}$. Level of this integration is though rather vague defined in the European Neighbourhood Policy Strategy Paper with a statement that "the implementation of the ENP itself brings with it the perspective of moving beyond cooperation to a significant degree of integration... including through a stake for partner countries in the EU's Internal Market" (European Commission, 2004, p. 8). It is the perspective of stake in the internal market that is supposed to be the main attraction of the ENP as an alternative to the full EU membership for the neighbour countries. The degree of integration of states at the level of single market would though require a high degree of harmonization of the relevant legislation and, when it comes to the EU, also acceptance of a significant part of the acquis communautaire regarding the EU internal market. In the event that any neighbour should have reached this level of integration with the EU, it would find itself de facto at the same level of integration as the EFTA states, which take part in the EU internal market

${ }^{7}$ Integration with the EU as the main integration grouping at least at the level of a free trade area but with no full EU membership

Slovak Journal of Political Sciences, Volume 12, 2012, No. 1

DOI: $10.2478 /$ sjps-2013-0003 
within the framework of the EEA. This integration process is not a simple one and requires a number of sequential steps with the aim to reach the highest level of bilateral trade liberalization possible.

According to classical economic theory - theory of economic integration (e.g. Balassa, 1961) the process of integration of countries has several stages. The lowest level of integration is creation of a free trade area. The basic condition for its formation is the removal of tariff and non-tariff barriers to trade between participating countries and liberalization of free movement of goods and services between them. The next stage of integration represents the customs union, which may be created after the harmonization of customs tariffs towards third countries and the introduction of Common Customs Tariff. The third stage of integration - the common market of countries - requires an even greater degree of liberalization and in addition to guaranteeing free movement of goods, it is necessary to ensure the free movement of services, capital and labour. The last stage of economic integration of countries lies in creation of an economic and monetary union, which requires harmonization of national macroeconomic policies. To complete the process of creating monetary union it is necessary to replace national currencies with a common currency and to establish a common monetary policy at the supranational level. The last stage of economic integration is also accompanied by the final step towards full integration of the countries, and that is creating a form of a political union of states. European integration currently offers the possibility of integration with the main integration structures - the EU - in the form of flexible exogenous integration up to the third stage of integration - the common market.

The European Neighbourhood Policy officially declares the possibility of closer integration of neighbouring countries up to the level of common market. However, the European Neighbourhood Policy Strategy Paper has not specified the prospect of participation of neighbours in the common market in detail. This perspective is "based on legislative and regulatory approximation, the participation in a number of EU programmes and improved interconnection and physical links with the EU". The document also presents the economic benefits that the ENP and gradual economic integration bring to the neighbour states. As for concrete steps towards closer integration of the countries, the strategy paper based those on the already existing obligations stemming from the provisions of the Euro-Mediterranean Partnership on the establishment of the Euro-Mediterranean free trade area on the part of the Mediterranean neighbours and from the provisions of the partnership and cooperation agreements on the part of the eastern neighbours. In the case of Mediterranean neighbours the ENP aims to "provide ways and means to deepen trade liberalisation and regional integration in coherence with the Euromed partnership", which envisages the creation of a free trade area for goods. On the other hand, the

Slovak Journal of Political Sciences, Volume 12, 2012, No. 1

DOI: 10.2478/sjps-2013-0003 
eastern neighbours should continue implementing the provisions of the partnership and cooperation agreements on trade. These are primarily a commitment to join the WTO, elimination of quantitative restrictions on imports of goods and implementation of various economic reforms. Only when these provisions are met, the Union will consider deeper trade and economic integration (Commission, 2004, p. 14-15). Specific procedures for achievement of the targets are contained in tailor-made action plans for individual neighbouring countries.

In its reform document, "A Strong European Neighbourhood Policy" published in 2007, the Commission proposed several improvements to facilitate the transition and integration of neighbouring countries. With regard to deepening of economic integration, a particularly important step was taken in the form of proposal of deep and comprehensive free trade agreements, which were supposed to be tailored to individual countries (and in doing so reflect the principle of differentiation). Key element of these agreements would be reduction of non-tariff barriers through regulatory convergence. These agreements should cover trade in goods and services between the EU and neighbouring states, and should include "strong legally binding provisions on the implementation of trade and economic regulatory issues" (Commission, 2007 , p. 4). Issues relating to free trade should be incorporated into the new generation of extended agreements with neighbouring countries. Country's integration into certain aspects of functioning of the EU should be assisted and facilitated besides the possibility of concluding a comprehensive free trade agreements also by the possibility of participating in various community programs and EU agencies.

More concrete steps towards closer integration of countries have been adopted by launching the regional initiative called the Eastern Partnership. Economic integration in the form of establishing a free trade area has become one of its priorities, both on bilateral as well as multilateral level. In its Communication to the European Parliament on the Eastern Partnership, the Commission has identified five main areas of cooperation and also concrete actions to be undertaken within these areas. One of the priorities is gradual integration into the EU economy. The primary objective of the Eastern Partnership in this sense is creation of a deepened and comprehensive free trade area, with an essential condition of entering the WTO. This free trade area should cover all trade between the countries, including energy trade, which is a top priority in mutual economic relations.

Closer political connection of partner countries with the EU is reinforced by the character of the new contractual arrangements introduced within the Eastern Partnership. They will provide the partner countries with an option to negotiate an association agreement with the EU involving also provisions on

Slovak Journal of Political Sciences, Volume 12, 2012, No. 1

DOI: 10.2478/sjps-2013-0003 
free trade between the two parties. The association agreement envisages deeper political commitment and closer links with EU standards and the acquis, including provisions relating to the common foreign and security policy. Gradual integration of the countries would also significantly contribute to visa liberalization, which is considered one of the cornerstones of the Eastern Partnership. It even offers a full abolition of visa requirements for countries that would meet all the conditions ${ }^{8}$. A. Duleba considers the prospect of gradual opening of the labour markets for citizens of partner countries, which is for the EU and particularly some Member States an extremely sensitive issue, to be an unprecedented phenomenon in the field of migration and mobility (Duleba, 2009). If such a provision becomes a reality in the future, it will be a significant step towards realizing the objective of integrating partner countries at the level of common market.

Both current platforms for EU's relations with its eastern neighbours, either the ENP or its institutionalized eastern dimension in the form of regional initiative - the Eastern Partnership, entail a politically declared bid for closer integration up to the level of common market. However, the specific form of the final offer is not clear. Official documents of the Union mention the "stake in the EU internal market." The first concrete step in this sense is the offer of deep and comprehensive free trade agreements for those partner countries that will be able to meet all the conditions required to achieve this lowest level of economic integration. Integration potential of both these platforms just depends on the ability of partner countries to adopt the required reforms, but also on the EU's ability to adequately stimulate the partner countries through financial or technical assistance, but especially to motivate them politically. The EU's offer to its neighbouring countries, particularly the east ones, is often criticized as unclear, vague and not bringing any direct and immediate benefits for the citizens of partner countries, which subsequently reflects in a lower confidence of the population and political elites of these countries in the transformative potential of the ENP.

Since the ENP, as well as the Eastern Partnership, offer the neighbour countries the possibility of integration with the EU at the level of common market, it can be naturally seen as an alternative to the EU enlargement, but in a sense, also as a preparatory phase of the accession process. If any of the neighbour countries manages to reach the integration level of the EFTA states, which could in case of sufficient political will become EU member states

\footnotetext{
${ }^{8}$ The main condition is signing of the pact on mobility and safety. Partner countries must comply with the EU norms in particular on issues of internal security, issuance of travel documents and border protection. They should also establish a central register of citizens, etc.
}

Slovak Journal of Political Sciences, Volume 12, 2012, No. 1

DOI: $10.2478 /$ sjps-2013-0003 
anytime, with regard to the Art. 49 of the Treaty on the European Union there will be no other formal obstacle for full integration of the neighbour countries. As we have already mentioned, fully exploited integration potential of the ENP could then lead to the creation of candidates eligible for membership (Cremona, Hillion, 2006). This is, however, a relatively long-term scenario. The question is what kind of integration scenario the EU's integration capacity will allow and if there is enough political will for these countries to be fully integrated. It is therefore necessary to search for politically feasible alternatives to the classic scenario of the EU enlargement process, which could take the form of different variants of the flexible exogenous integration.

\section{Conclusions}

Creation of the European Neighbourhood Policy was a smart move with regard to the massive EU enlargement of 2004. The end of the Cold War era gave rise to ambitions of most of the Central and Eastern European countries to become part of the European Union which they considered to be a successful integration project stimulating economic growth of its members and bringing wealth and stability to them. The protracted reform process the EU has experienced for the past fifteen years and that sought to adapt the Union to the new conditions of enlarged membership as well as to changed external environment ${ }^{9}$ has proved that the EU needs to reconsider its further enlargement carefully. With a political commitment to sooner or later admit all the Western Balkan states there was an urgent need to tackle also the integration ambitions of the rest of the Eastern European states. With this aim, the EU has come up with a policy framework that could cover the relations with these countries, help them establish closer links with the Union and enjoy some benefits stemming from this special relationship but at the same time being membership neutral.

Accepting new member states to the EU is always a question of political will and consensus of all the existing members. With regard to the eastern neighbours the fact is that they are neither now nor will they be in the foreseeable future ready to comply with the criteria for EU membership. On the other hand, there is the sensitive issue of these countries' close ties to the Russian federation which considers them its own sphere of influence. Nevertheless, the EU seeks to have stable, secure and prosperous neighbourhood and by means of the European Neighbourhood policy, which was significantly modelled on the enlargement policy, it helps those countries with their transformation processes. The ENP as well as the Eastern

${ }^{9}$ Mostly influenced by the globalization and in the recent years also the connected global economic crisis.

Slovak Journal of Political Sciences, Volume 12, 2012, No. 1

DOI: $10.2478 /$ sjps-2013-0003 
partnership, as laid down in their official documents, offer the possibility of high degree of integration with the EU but with no certain membership perspective. The EU currently finds itself in a very complicated situation when it has to strive to secure its very own existence and has to cope with the challenging question of its further development. The Union needs countries with strong and stable economies and we assume that in the future it will very careful in admitting new members in this regard. Therefore the ENP could be now regarded only as a transformative policy. However, if the best scenario is considered and the ENP actually creates an eligible candidate the issue of (in)sufficient political will and probably also integration capacity will arise.

In our opinion, this complicated situation could be solved by applying of the principles of flexible (exogenous) integration, namely, variable geometry, in relation to EU Eastern Neighbourhood countries and their integration ambitions. Such an approach would address the problem of the need to distinguish between the European partner countries under the ENP, which are eligible for membership, and non-European partner countries that do not qualify for membership. It would also be a compromise between the current EU position on one side and position of neighbours on the other. Flexible integration of partner countries based on a rigorous conditionality could also address many problematic aspects of the Union's integration capacity. Current events show that the principles of flexible integration (e.g. the two-speed Europe or variable geometry) will be of more use within the European integration during the upcoming period ${ }^{10}$ and if there is enough political will and sufficient progress made by the eastern European ENP countries they could be applied also in this regard.

\section{REFERENCES}

Cremona, M. - Hillion, CH. 2006. L'Union fait la force? Potential and Limitations of the European Neighbourhood Policy as an Integrated EU Foreign and Security Policy. EUI Working Paper LAW No. 2006/39, European University institute, Department of Law, 2006. ISSN 1725-6739, 25 p.

Duleba, A. 2009. Východné partnerstvo: čo prináša a na čo zabúda? [online]. In .týždeň, No. 39/2009, [cit. 21. 10. 2009]. Available at:

$<$ http://www.tyzden.sk/casopis/2009/36/vychodne-partnerstvo-co-prinasaa\%C2\%A0na-co-zabuda.html >

European Commission. 2003a. Wider Europe - Neighbourhood: A New Framework for Relations with our Eastern and Southern Neighbours, Brussels, 11. March 2003.

European Commission. 2003b. Paving the way for a New Neighbourhood Instrument, Communication from the Commission, Brussels, 1. July 2003.

\footnotetext{
${ }^{10}$ With regard to the European Monetary Union.
}

Slovak Journal of Political Sciences, Volume 12, 2012, No. 1

DOI: $10.2478 /$ sjps-2013-0003 
European Commission. 2004. European Neighbourhood Policy. Strategy paper. Communication from the Commission. Brussels, 12. May 2004.

European Commission. 2007. A Strong European Neighbourhood Policy. Communication from the Commission. Brussels, 5. December 2007.

Gebhard, C. 2007. Assesing the EU Actorness Towards its "Near Abroad" The European Neighbourhood Policy. [online] Cyprus Center of European and Interantional Affairs. Paper No. 2007/05 (November) [cit. 10.2.2010] Available at: $<$ http://www.cceia.unic.ac.cy/pdf_files/Carmen\%20Gebhard\%20\%20Assessing\%2 0EU\%20Actorness\%20Towards\%20its\%20\%27Near\%20Abroad\%27\%20\%202007 -\%2003\%20\%28November\%29.pdf>

Johnston, I. 2001. Treating International Institutions as Social Environments. In International Studies Quarterly, Vol. 45, 2001, No. 4, ISSN 0020-8833, p. 487-516.

Kelley, J. 2006. New Wine in Old Wineskins: Promoting Political Reforms through the New European Neighbourhood Policy. In Journal of Common Market Studies, Vol. 44, 2006, No. 1. p. 29-55.

Kratochvíl, P. 2006. The European Neighbourhood Policy: A Clash of Incompatible Interpretations. In KRATOCHVÍL, P. (eds.) 2006. The European Union and its Neighbourhood: Policies, Problems and Priorities. Prague: Institute of International Relations, 2006. ISBN 80-86506-56-8, p. 13-28.

Landaburu, E. 2006. From Neighbourhood to Integration Policy: Are there concrete alternatives to enlargement?. [online]. CEPS Policy Brief No. 95, 1 March 2006. [cit. 10.6.2009]. Available at: <http://aei.pitt.edu/6600/01/1305_95.pdf $>$

Magen, A. 2006. The Shadow of Enlargement: Can the European Neigbourhood Policy Achieve Compliance? In The Columbia Journal of European Law. Vol. 12, 2006, No. 2, ISSN 1076-6715, p. 383-427.

Meloni, G. 2007. Is the Same Toolkit Used during Enlargement Still Aplicable to the Countries of the New Neighbourhood? A Problem of Mismatching between Objectives and Instruments. In Cremona, M. - Meloni, G. (eds.) 2007. The European Neighbourhood Policy: A Framework for Modernisation? [online]. EUI Working Paper LAW No. 2007/21. ISSN 1725-6739. p. 97-112. [cit. 20.10.2008] Available at: $<\mathrm{http}$ :/cadmus.iue.it/dspace/bitstream/1814/6976/1/LAW-2007-21.pdf >

Pierson, P. 1996. The Path to European Integration. A Historical Institutionalist Analysis. In Comparative Political Studies, Vol. 29, 1996, No. 2, p. 123-163.

Prodi, R. 2002. A Wider Europe - A Proximity Policy as the Key to Stability. Speech at the Sixth ECSA-World Conference in Brussels, 5.-6. December 2002.

Tassinari, F. 2005. Security and Integration in the EU Neighbourhood. The Case of Regionalism. CEPS Working Document No. 226/July 2005, Brussels: Centre for European Policy Studies. ISBN 92-9079-582-0, 26 s.

Tulmets, E. 2006. Adapting the Experience of Enlargement to the Neighbourhood Policy : The ENP as a Substitute to Enlargement? In Kratochvíl, P. (ed.). The EU and its Neighbourhood: Policies, Problems, Priorities, Prague: Institute of International Relations, 2006, p. 16-34.

Slovak Journal of Political Sciences, Volume 12, 2012, No. 1

DOI: $10.2478 /$ sjps-2013-0003 
PhDr. Veronika Sklenková, PhD. graduated from International Relations at the Faculty of Political Sciences and International Relations of the Mathias Bell University in Banská Bystrica. Currently, she is an assistant professor at the Faculty of Social Sciences of the University of Ss. Cyril and Methodius in Trnava. She also holds the post of Vice-dean for foreign relations at the Faculty of Social Sciences. She mainly specializes in the topic of European integration evolution and various aspects of functioning of the European Union.

PhDr. Veronika Sklenková, PhD. University of Ss. Cyril and Methodius

Faculty of Social Sciences

Department of European Studies

Bučianska 4/A

91701 Trnava

veronika.sklenkova@ucm.sk

DOI: $10.2478 /$ sjps-2013-0003 